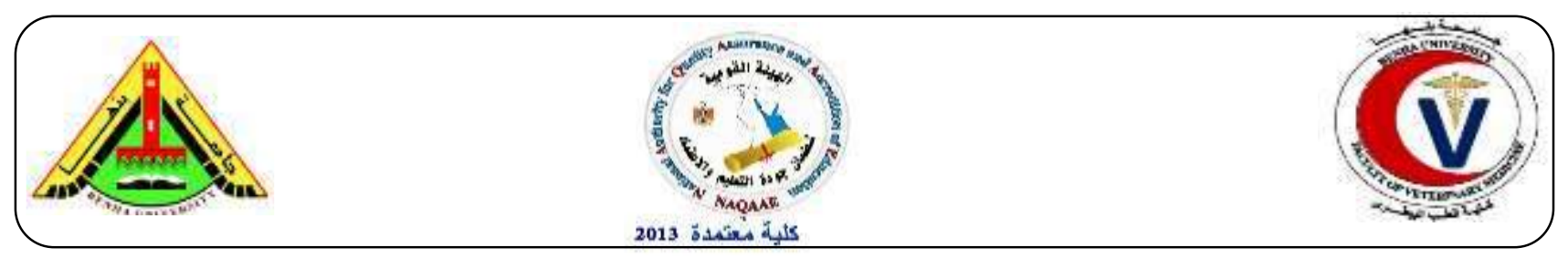

\title{
Antibacterial efficiency of both natural and chemical compounds in minced meat
}

\author{
Hemmat El gendy ${ }^{1}$, Faten Hasanine ${ }^{1}$, Amani Mohamed Salem ${ }^{1}$, Nahla Ahmed Abo Elroos ${ }^{2}$ \\ ${ }^{1}$ Department of Food Hygiene, Faculty of Veterinary Medicine, Benha University \\ ${ }^{2}$ Animal Health Research Institute, Shibin El Kom Branch, Egypt
}

\section{A B S T R A C T}

A total of $4200 \mathrm{~g}$ fresh minced beef samples were divided into both large 2 groups, the first group (A) for E.coli and the second (B) for S.aureus then each group was divided into 7 equal subgroups (100g of each). Escherichia coli was inoculated into the first 7 subgroups with $4 \times 106 \mathrm{cfu} / \mathrm{g}$ and S.aureus was inoculated into the second 7 subgroups with $3 \times 106 \mathrm{cfu} / \mathrm{g}$. The first (A) group was inoculated with cinnamon, garlic and rosemary at concentration of (1\%) separately and the second (B) group was inoculated with nisin $(100 \mathrm{ppm})$, sodium nitrite $(100 \mathrm{ppm})$ and potassium sorbate $(0.2 \%)$. The inoculated samples were stored at $4 \pm 1^{\circ} \mathrm{C}$ in refrigerator till be used. The inoculated subgroups were examined at zero time, 3rd, 6th and 9thdays for bacterial count. The highest effect with $100 \%$ reduction of E.coli was in group (A) for rosemary and garlic oils at 9th days of storage. Also, the highest effect of chemical compounds on E.coli was achieved by nisin (100ppm) at 6th \& 9th days of storage with reduction percentage $99.99 \% \& 99.76 \%$, respectively. On other hand, the highest effect with $100 \%$ reduction percentage was in group (B) artificially inoculated with S.aureus was for rosemary oil at 6th and 9th day of storage .Also, the highest effect of (100\% reduction) of nisin on S.aureus was indicated at9th days of storage. Generally, essential oils proved to be efficient similar to chemical preservatives in addition to their safety for human consumption.

Keywords: Minced meat, E.coli, S. aureus, essential oils, chemical preservatives.

Received: 11 June 2019, Accepted: 28 August 2019 (http://www.bvmj.bu.edu.eg) (BVMJ-36(2): 138-149, 2019)

\section{INTRODUCTION}

Meat is a nutritious protein -rich food which is highly perishable and has a short-life unless preservation methods are used (Olaoye and Onilude, 2010). However, it gets easily contaminated by pathogenic microorganisms present in animal prior to slaughter. It is therefore important to make meat safe for consumers in terms of stability, transportation and storage.

Shelf life and maintenance of meat quality are influenced by a number of inter-related factors including holding temperature, which can result in determinable changes in the quality attributes of meat. Spoilage by microbial growth is the most important factor in relation to keeping quality of meat (Lambert et al., 1991).

As the food industry is facing great challenges to produce safe and at the same time food without synthetic chemical preservatives. So the essential oils make their way into the scientific focus, due to their antibacterial and antioxidant properties, they are used to prevent food borne diseases and extend shelf-life and 
to improve some meat characteristics (Akthar et al., 2014).

Cinnamon can be used to obtain sweet flavoring and spicy characteristics, easily absorbed and do not have any adverse effects. It also plays an important role in pharmacological effects such as: carminative, stomachic, astringent, stimulant, antiinflammatory, antimicrobial, antioxidant, antispasmodic, antiulcer and treating the common cold (Mishra and Behak, 2010).

Garlic is one of the most commonly used ingredients as a flavor enhancement. Garlic has a wide spectrum of actions, not only antibacterial, antifungal and antiprotozoal, but also it has beneficial effects on the cardiovascular and immune systems (Harris et al., 2001). During the last decade, the antimicrobial activity of garlic and garlic derived organosulfur compounds was widely investigated against both food spoilage bacteria and food borne pathogens (Leuschner and Ielsch, 2003).

Rosemary, the antioxidant activity of rosemary extracts has been primarily related to two phenolic diterpenes: carnosic acid and carnosol (Frankel et al., 1996). Several compounds found in this oil have been reported to be inhibitory to several microorganisms (Mangena and Muyima, 1999).

In Concern to meat products, good quality and improvements in equipment of production and hygiene were recommended to reduce contamination of meat products (Depoureq and Poucke, 1991). In addition to chemical preservatives which have been used as additional barriers to limit the number of microorganisms capable to grow in foods through inactivating or inhibiting the growth of undesirable microorganisms. Many methods of preservation are available to food processors including thermal processing, refrigeration, addition of chemical preservatives or a combination of these methods, but customer preferences have led researches to develop the use of natural inhibitors from plant, animal, and microbial sources (Shahidi et al., 1991).

Nisin is the only one internationally accepted as a safe and natural food bio preservative in certain foods for several decades (Papagianni and Anastasiadou, 2009). Nisin is a broad spectrum bacteriocin with bactericidal activity, even in very low concentrations, towards a wide range of Gram -positive bacteria, including S.aureus (Parada et al., 2007).

Sodium nitrite $(50 \mathrm{ppm})$ has a role in meat products by stabilizing the pink coloration of meat and enhances the meat product flavor (Eleiwa- Nesreen, 2003). Nitrite is considered as an essential curing ingredient responsible for fixing the characteristic color associated with cured meats, creating a unique flavor profile that is distinguishable from products not containing nitrite, providing control of the oxidation of lipids, and serving as an effective antimicrobial by itself or synergistically with other ingredients (Pegg, 2004).

Potassium sorbate is used to improve microbial quality of the meat and increase its shelf -life. It did not cause and adverse effect on the quality characteristics of the meat (Hussein et al., 2012).

It is known that the effectiveness of preservatives depend not only on their concentration and type, but also on the species of microorganism on which they act. Experiment results of preservatives combinations exhibited synergistic effects (Stanojevic et al., 2009).

Control of food poisoning bacteria remain an important objective for sectors of food production industry, Therefore, the main goal of the present work was carried out to evaluate the efficacy of some essential oils and chemical preservatives against two serious pathogens (E. coli and S.aureus) in minced beef stored at $4 \pm 1^{\circ} \mathrm{C}$. 


\section{Materials and methods}

\subsection{Bacterial strains:}

Escherichia coli and S.aureus strain were obtained from Media Unite, Food Hygiene Department, Animal Health Research Institute, Dokki, Giza, Egypt, with recommended dose $104 \mathrm{cfu} / \mathrm{ml}$ for E.coli and $106 \mathrm{cfu} / \mathrm{ml}$ for S.aureus.

\subsection{Natural oil :}

Cinnamon oil (1\%), garlic oil (1\%) and rosemary oil $(1 \%)$, were purchased from $\mathrm{El}$ Captain Company (CAP PHARM), Al-Obour City- Cairo-Egypt.

\subsection{Chemical preservatives :}

- Nisine 10ppm

- Sodium Nitrite 100ppm

- Potassium Sorbate $0.2 \%$

\subsection{Experimental application:}

Accurately, $4200 \mathrm{~g}$ of the fresh minced beef used in this study was purchased from butcher shops in El Menofia Governorate. The minced beef samples were immediately prepared and divided into two main groups (2100 $\mathrm{g}$ of each) and then sterilized in Gamma irradiation units, The Egyptian Atomic Energy Authority (EAEA), Naser city, Cairo. Egypt as recorded by (Huq et al., 2013).Each group divided into equal7 subgroups $(3 \times 100 \mathrm{~g}$ of each). The first 7 subgroups were inoculated with E.coli $(4 \times 106 \mathrm{cfu} / \mathrm{g})$ and the other 7 subgroup were inoculated with S.aureus $(3 \times 106 \mathrm{cfu} / \mathrm{g})$.

\section{1st Group:}

Control +ve: inoculated with E.coli strain only.

A: Treated with garlic oil1\%+E.coli strain.

B: Treated with cinnamon oil $1 \%+$ E.coli strain.

C: Treated with rosemary oil1\%+E.coli strain.

D: Treated with nisin 100ppm + E.coli strain.

$\mathrm{E}$ : Treated with sodium nitrite $100 \mathrm{ppm}+$ E.coli strain.

F: Treated with potassium sorbate $0.2 \%+$ E.coli strain.

2 nd Group:
Control +ve: inoculated with S.aureus strain only.

A: Treated with garlic oil1\%+ S.aureus strain.

B: Treated with cinnamon oil $1 \%+$ S.aureus strain.

C: Treated with rosemary oil1\%+ S.aureus strain.

D: Treated with nisin 100ppm+ S.aureus strain.

E: Treated with sodium nitrite 100ppm+ S.aureus strain.

F: Treated with potassium sorbate $0.2 \%+$ S.aureus strain.

The inoculated samples were stored at $\left(4 \pm 1^{\circ} \mathrm{C}\right)$ till be used .The inoculated subgroups were examined at $3^{\text {rd }}$, 6th and $9^{\text {th }}$ days of inoculation for:

Sensory examination: The color, odor and overall acceptability were determined for each sample of meat according to (Fik and Fik, 2007).

E.coli and S.aureus counts according to (FDA, 2002).

The experiment was performed in triplicate.

2.5. Reduction percentage:

Reduction $=\frac{\text { Initial load }- \text { new count }}{\text { Initial load }}$

\subsection{Statistical Analysis:}

The obtained results were statistically evaluated by application of Analysis of Variance (ANOVA) test according to Rosner (2002).

\section{RESULTS}

Table (1\& 2) revealed that sensory analysis of control (untreated sub groups) remain accepted until $2^{\text {nd }}$ days while treated subgroups with Cinnamon $1 \%$ \& potassium sorbate $(0.2 \%)$ remain accepted until $6^{\text {th }}$ days of storage. Garlic oil 1\% \&sodium nitrite (100ppm) remain accepted until 6 th and $9^{\text {th }}$ days of storage. Moreover, rosemary oil (1\%) and nisin (100ppm) showed good grade at $6^{\text {th }}$ day and acceptable at $9^{\text {th }}$ days. 
From the obtained results there was decline of sensory attributes begin after the first day of storage, with marked reduction of odor in case of oils mainly in garlic oil (pungent odor)

Table (3) illustrated the antimicrobial effects and reduction percentage of cinnamon, garlic and rosemary oils at concentration (1\%) on counts of E.coli artificially inoculated into minced beef. Cinnamon oil $(1 \%)$ decreased count of E.coli from $4 \times 10^{6}$ (initial load )to $1.68 \times 10^{6} \pm 0.4 \times 10^{6} \mathrm{cfu} / \mathrm{g}, 6.29 \times 10^{5} \pm 1.1 \times 10^{5}$ $\mathrm{cfu} / \mathrm{g}$ and $3.51 \times 10^{5} \pm 0.7 \times 10^{5} \mathrm{cfu} / \mathrm{g}$ with reduction percentage $58 \%, 84.27 \%$ \& $91.23 \%$ on $3^{\text {rd }}, 6^{\text {th }}$ and $9^{\text {th }}$ days of storage, respectively. Garlic oil (1\%) decreased counts of E.coli to $7.12 \times 10^{5} \pm 1.5 \times 10^{5}, 4.53 \times 10^{4} \pm 0.8 \times 10^{4} \mathrm{cfu} / \mathrm{g}$ at $3^{\text {rd }}$ and $6^{\text {th }}$ days of storage with reduction $\%$ $85.21 \%$ and $98.87 \%$ and complete reduction $(100 \%)$ of E.coli count was attained at $9^{\text {th }}$ days. Rosemary oil (1\%) decreased count of E.coli at $3^{\text {rd }}$ and $6^{\text {th }}$ days of storage to $9.84 \times 10^{3} \pm 2.0 \times 10^{4}$ $\mathrm{cfu} / \mathrm{g}$ and $1.6 \times 10^{3} \pm 0.2 \times 10^{2}$ with reduction percentage $99.75 \%$ \& $99.9 \%$ and not detected count of E.coli at $9^{\text {th }}$ days of storage with reduction percentage $100 \%$.

Table (4) declared the effects and reduction percentage of potassium sorbate $(0.2 \%)$, sodium nitrite (100ppm) and nisin (100ppm) on counts of E.coli artificially inoculated into minced beef. Potassium sorbate (0.2\%) decreased count of E.coli from $4 \times 10^{6}$ (initial load) to $2.15 \times 10^{6} \pm 0.3 \times 10^{6}$ $\mathrm{cfu} / \mathrm{g}, 1.07 \times 10^{6} \pm 0.1 \times 10^{6} \mathrm{cfu} / \mathrm{g}$ and $5.93 \times 10^{5} \pm$ $0.9 \times 10^{5} \mathrm{cfu} / \mathrm{g}$ with reduction percentage $46.25 \%, 73.25 \%$ and $85.17 \%$ on $3^{\text {rd }}, 6^{\text {th }}$ and $9^{\text {th }}$ days of storage, respectively. Sodium nitrite (100ppm) decreased counts of E.coli to $1.30 \times 10^{6} \pm 0.2 \times 10^{6}, 3.65 \times 10^{5} \pm 0.5 \times 10^{5}$ and $9.47 \times 10^{3} \pm 2.1 \times 10^{5} \mathrm{cfu} / \mathrm{g}$ at $3^{\text {rd }}, 6^{\text {th }}$ and $9^{\text {th }}$ days of storage with reduction $\% 67.50 \%$, $90.88 \%$ and $99.76 \%$, respectively. Nisin (100ppm) decreased count of E.coli to $5.19 \times 10^{5} \pm 1.0 \times 10^{5}, \quad 8.33 \times 10^{3} \pm 1.6 \times 10^{3} \quad \&$
$9.45 \times 10^{2} \pm 1.9 \times 10^{2} \quad \mathrm{cfu} / \mathrm{g}$ with reduction percentage $87.03 \%, 99.79 \% \& 99.995$ at $3^{\text {rd }}, 6^{\text {th }}$ and $9^{\text {th }}$ days of storage, respectively.

Table (5) illustrated the antimicrobial effects and reduction percentage of cinnamon, garlic and rosemary oils at concentration (1\%) on counts of S.aureus artificially inoculated into minced beef. Cinnamon oil (1\%) decreased count of S.aureus from $3 \times 10^{6}$ (initial load) to $1.02 \times 10^{6} \pm 0.1 \times 10^{6} \mathrm{cfu} / \mathrm{g}, 3.41 \times 10^{5} \pm$ $0.6 \times 10^{5} \mathrm{cfu} / \mathrm{g}$ and $9.67 \times 10^{4} \pm 1.8 \times 10^{5} \mathrm{cfu} / \mathrm{g}$ with reduction percentage $66 \%, 88.63 \% \& 96.78 \%$ on $3^{\text {rd }}, 6^{\text {th }}$ and $9^{\text {th }}$ days of storage, respectively. Garlic oil (1\%) decreased counts of S.aureus to $4.29 \times 10^{5} \pm 0.8 \times 10^{5}$ and $1.73 \times 10^{4} \pm 0.4 \times 10^{4}$ $\mathrm{cfu} / \mathrm{g}$ at $3^{\text {rd }}$ and $6^{\text {th }}$ days of storage with reduction \% 85.21\% and 99.425 and not detected S.aureus count at $9^{\text {th }}$ days with $\mathrm{R} \%$ $100 \%$. Rosemary oil (1\%) decreased count of S.aureus at $3^{\text {rd }}$ day of storage to $2.50 \times 10^{4} \pm$ $0.3 \times 10^{4} \mathrm{cfu} / \mathrm{g}$ with reduction percentage $99.17 \%$ and not detected count of S.aureus at $6^{\text {th }}$ and $9^{\text {th }}$ days of storage with reduction percentage $100 \%$.

Table (6) pointed out the antimicrobial effects and reduction percentage of potassium sorbate $(0.2 \%)$, sodium nitrite $(100 \mathrm{ppm})$ and nisin (100ppm) on counts of S.aureus artificially inoculated into minced beef. Potassium sorbate $(0.2 \%)$ decreased count of S.aureus from $3 \times 10^{6}$ (initial load) to $1.46 \times 10^{6} \pm 0.3 \times 10^{6} \mathrm{cfu} / \mathrm{g}, 8.36 \times 10^{5} \pm 1.4 \times 10^{5}$ $\mathrm{cfu} / \mathrm{g}$ and $1.58 \times 10^{5} \pm 0.3 \times 10^{5} \mathrm{cfu} / \mathrm{g}$ with reduction percentage $51.33 \%, 72.13 \%$ and $94.73 \%$ on $3^{\text {rd }}, 6^{\text {th }}$ and $9^{\text {th }}$ days of storage, respectively. Sodium nitrite(100ppm) decreased counts of S.aureus to $7.70 \times 10^{5} \pm$ $2.1 \times 10^{5}, 1.61 \times 10^{5} \pm 0.3 \times 10^{5}$ and $5.24 \times 10^{3} \pm$ $1.4 \times 10^{5} \mathrm{cfu} / \mathrm{g}$ at $3^{\text {rd }}, 6^{\text {th }}$ and $9^{\text {th }}$ days of storage with reduction $\% 74.33 \%, 94.63 \%$ and $99.82 \%$, respectively. Nisin (100ppm) decreased count of $S$. aureus to $1.04 \times 10^{5} \pm 0.1 \times 10^{5}$, $1.10 \times 10^{4} \pm 0.2 \times 10^{3} \quad \mathrm{cfu} / \mathrm{g}$ with reduction 
percentage $96.53 \%, 99.63 \% \& 100 \%$ at $3^{\text {rd }}, 6^{\text {th }}$

and $9^{\text {th }}$ days of storage ,respectively.

Table1: Changes in sensory traits of control and essential oil (1\%) treated minced meat stored at $4 \pm 1{ }^{\circ} \mathrm{C}(\mathrm{n}=5)$.

\begin{tabular}{rcccccc} 
Trait & Color & odor & Appearance & Consistenc & Overall \\
Storage time & $(5)$ & $(5)$ & $(5)$ & y (5) & (5) & Grade \\
\hline
\end{tabular}

1. Control:

$\begin{array}{lcccccc}\text { Zero time } & 5 & 5 & 5 & 5 & 5 & \text { Very good } \\ 3 \text { days } & 2.2 & 2.0 & 2.6 & 2.4 & 2.3 & \text { Unacceptable } \\ 6 \text { days } & 1.0 & 1.2 & 1.0 & 1.0 & 1.1 & \text { Bad } \\ 9 \text { days } & \mathrm{S} & \mathrm{S} & \mathrm{S} & \mathrm{S} & \mathrm{S} & \text { Spoiled }\end{array}$

2. Cinnamon oil:

$\begin{array}{lcccccc}\text { Zero time } & 5 & 5 & 5 & 5 & 5 & \text { Very good } \\ 3 \text { days } & 4.0 & 3.6 & 4.2 & 3.8 & 3.9 & \text { Good } \\ 6 \text { days } & 3.4 & 2.6 & 3.2 & 3.0 & 3.1 & \text { Acceptable } \\ 9 \text { days } & 2.6 & 2.2 & 2.0 & 2.4 & 2.3 & \text { Unacceptable }\end{array}$

3. Garlic oil:

$\begin{array}{lcccccc}\text { Zero time } & 5 & 5 & 5 & 5 & 5 & \text { Very good } \\ 3 \text { days } & 4.2 & 3.8 & 4.0 & 4.2 & 4.1 & \text { Good } \\ 6 \text { days } & 3.6 & 3.0 & 3.4 & 3.6 & 3.4 & \text { Acceptable } \\ 9 \text { days } & 3.2 & 2.6 & 3.0 & 3.2 & 3.0 & \text { Acceptable }\end{array}$

4. Rosmary oil:

\begin{tabular}{rrrrrrr} 
Zero time & 5 & 5 & 5 & 5 & 5 & Very good \\
3 days & 4.4 & 4.2 & 4.0 & 4.4 & 4.3 & Good \\
6 days & 4.0 & 3.6 & 3.8 & 4.2 & 4.0 & Good \\
9 days & 3.2 & 3.0 & 3.4 & 3.0 & 3.2 & Acceptable \\
\hline 5: Very good & 4: Good & & 3: Acceptable & \\
2: Unacceptable & 1: $\mathrm{Bad}$ & & S: Spoiled &
\end{tabular}


Table 2: Changes in sensory traits of control and chemical preservatives treated minced meat stored at $4 \pm 1^{\circ} \mathrm{C}(\mathrm{n}=5)$.

\begin{tabular}{|c|c|c|c|c|c|c|}
\hline$\underbrace{\text { Trait }}_{\text {Storage time }}$ & $\begin{array}{l}\text { Color } \\
(5)\end{array}$ & $\begin{array}{l}\text { odor } \\
(5)\end{array}$ & $\begin{array}{l}\text { Appearanc } \\
\text { e (5) }\end{array}$ & $\begin{array}{l}\text { Consistenc } \\
\text { y (5) }\end{array}$ & $\begin{array}{l}\text { Overal } \\
1 \quad(5)\end{array}$ & Grade \\
\hline
\end{tabular}

1. $\underline{\text { Control: }}$

$\begin{array}{lcccccc}\text { Zero time } & 5 & 5 & 5 & 5 & 5 & \text { Very good } \\ 3 \text { days } & 2.2 & 2.0 & 2.6 & 2.4 & 2.3 & \text { Unacceptable } \\ 6 \text { days } & 1.0 & 1.2 & 1.0 & 1.0 & 1.1 & \text { Bad } \\ 9 \text { days } & \mathrm{S} & \mathrm{S} & \mathrm{S} & \mathrm{S} & \mathrm{S} & \text { Spoiled }\end{array}$

2. Pot. Sorbate $(0.2 \%)$ :

$\begin{array}{lcccccc}\text { Zero time } & 5 & 5 & 5 & 5 & 5 & \text { Very good } \\ 3 \text { days } & 4.2 & 3.6 & 4.4 & 3.8 & 4.0 & \text { Good } \\ 6 \text { days } & 3.4 & 2.8 & 3.6 & 3.4 & 3.3 & \text { Acceptable } \\ \text { 9 days } & 2.8 & 2.0 & 2.2 & 2.6 & 2.4 & \text { Unacceptable }\end{array}$

3. Sod. Nitrite (100

ppm):

Zero time

$\begin{array}{llllllc}3 \text { days } & 4.4 & 4.0 & 4.2 & 4.4 & 4.3 & \text { Good } \\ 6 \text { days } & 3.6 & 3.2 & 3.4 & 3.8 & 3.5 & \text { Acceptable } \\ 9 \text { days } & 3.2 & 2.8 & 3.0 & 3.4 & 3.1 & \text { Acceptable }\end{array}$

4. $\underline{\operatorname{Nisin}(100 \mathrm{ppm}) \text { : }}$

$\begin{array}{rlccccc}\text { Zero time } & 5 & 5 & 5 & 5 & 5 & \text { Very good } \\ 3 \text { days } & 4.4 & 4.2 & 4.2 & 4.6 & 4.4 & \text { Good } \\ 6 \text { days } & 4.2 & 4.0 & 4.0 & 4.2 & 4.1 & \text { Good } \\ 9 \text { days } & 3.2 & 3.4 & 3.2 & 3.4 & 3.3 & \text { Acceptable } \\ \text { 5: Very good } & 4: \text { Good } & & \text { 3: Acceptable } & \\ \text { 2: Unacceptable } & \text { 1: Bad } & & \text { S: Spoiled } & \end{array}$


Table 3: The effects and Reduction \% of different essential oils on E.coli counts (cfu/g) inoculated into minced meat samples $(n=5)$.

\begin{tabular}{|c|c|c|c|c|c|c|c|c|}
\hline \multirow{2}{*}{$\begin{array}{l}\text { Treatment } \\
\text { Storage time }\end{array}$} & \multirow{2}{*}{$\begin{array}{l}\text { Control } \\
\text { Count }\end{array}$} & \multicolumn{3}{|c|}{ Cinnamon $1 \%$} & \multicolumn{2}{|l|}{ Garlic oil $1 \%$} & \multicolumn{2}{|l|}{ Rosemary oil $1 \%$} \\
\hline & & $\mathrm{R} \%$ & Count & $\mathrm{R} \%$ & Count & $\%$ & Count & $\mathrm{R} \%$ \\
\hline Zero time & $4.0 \times 10^{6} \pm 0.1 \times 10^{6}$ & )$^{6}-$ & $4.0 \times 10^{6} \pm 0.1 \times 10^{6}$ & -4.0 & $4.0 \times 10^{6} \pm 0.1 \times 10^{6}$ & - & $4.0 \times 10^{6} \pm 0.1 \times 10$ & $10^{6}$ \\
\hline $3^{\text {rd }}$ days 3 & $3.87 \times 10^{6} \pm 0.2 \times 10^{6}$ & 3.25 & $1.68 \times 10^{6} \pm 0.4 \times 10^{6}$ & $58 \quad 7.1$ & $7.12 \times 10^{5} \pm 1.5 \times 10^{5} 8$ & 82.21 & $9.84 \times 10^{3} \pm 2.0 \times 10^{4}$ & 99.75 \\
\hline $6^{\text {th }}$ day & $3.69 \times 10^{6} \pm 0.3 \times 10^{6}$ & 7.75 & $6.29 \times 10^{5} \pm 1.1 \times 10^{5}$ & 584.27 & $274.53 \times 10^{4} \pm 0.8 \times 10^{2}$ & $0^{4} \quad 98.87$ & $1.6 \times 10^{3} \pm 0.2 \times 10^{2}$ & 99.9 \\
\hline $9^{\text {th }}$ days 3 & $3.52 \times 10^{6} \pm 0.1 \times 10^{6}$ & 12 & $3.51 \times 10^{5} \pm 0.7 \times 10^{5}$ & 591.23 & ND & 100 & ND & 100 \\
\hline
\end{tabular}

$\mathrm{R} \%{ }^{*}=$ Reduction $\%$

Table 4: The effects and Reduction \% of some chemical preservatives on E.coli counts (cfu/g) inoculated into minced meat samples $(\mathrm{n}=5)$.

\begin{tabular}{|c|c|c|c|c|c|c|c|c|}
\hline \multirow{2}{*}{$\begin{array}{l}\text { Treatment } \\
\text { Storage time }\end{array}$} & Control & \multicolumn{2}{|c|}{$0.2 \%$ Potassium sorbate } & \multicolumn{2}{|c|}{ 100ppm Sodium nitrite } & \multicolumn{2}{|r|}{$100 \mathrm{ppm}$ nisin } & \multirow[b]{2}{*}{$\mathrm{R} \%$} \\
\hline & e Count & & Count & $\%$ & Count & $\mathrm{R} \%$ & Count & \\
\hline Zero time 4 . & $.0 \times 10^{6} \pm 0.1 \times 10^{6}$ & - & $4.0 \times 10^{6} \pm 0.1 \times 10^{6}$ & - & $4.0 \times 10^{6} \pm 0.1 \times 10^{6}$ & - & $4.0 \times 10^{6} \pm 0.1 \times 10^{6}$ & - \\
\hline $3^{\text {rd }}$ days 3.87 & $7 \times 10^{6} \pm 0.2 \times 10^{6}$ & 3.25 & $2.15 \times 10^{6} \pm 0.3 \times 10^{6}$ & 46.25 & $1.30 \times 10^{6} \pm 0.2 \times 10^{6}$ & 67.50 & $5.19 \times 10^{5} \pm 1.0 \times 10^{5}$ & 87.03 \\
\hline $6^{\text {th }}$ days $3 . .6$ & $59 \times 10^{6} \pm 0.3 \times 10^{6}$ & 7.75 & $51.07 \times 10^{6} \pm 0.1 \times 10^{6}$ & 73.25 & $3.65 \times 10^{5} \pm 0.5 \times 10^{5}$ & 590.88 & $8 \quad 8.33 \times 10^{3} \pm 1.6 \times 10^{3}$ & 99.79 \\
\hline $9^{\text {th }}$ days 3.52 & $2 \times 10^{6} \pm 0.1 \times 10^{6}$ & 12 & $5.93 \times 10^{5} \pm 0.9 \times 10^{5}$ & 85.17 & $9.47 \times 10^{3} \pm 2.1 \times 10^{5}$ & 99.76 & $69.45 \times 10^{2} \pm 1.9 \times 10^{2}$ & 99.99 \\
\hline
\end{tabular}

Table 5: The effects and Reduction \% of different essential oils on S. aureus counts (cfu/g) inoculated into minced meat samples $(n=5)$.

\begin{tabular}{lcccccccc}
\hline $\begin{array}{l}\text { Treatment } \\
\text { Storage time }\end{array}$ Count & R\% & Count & R\% & Count & R\% & Count & R\% \\
\hline Zero time & $3.0 \times 10^{6} \pm 0.1 \times 10^{6}$ & - & $3.0 \times 10^{6} \pm 0.1 \times 10^{6}$ & - & $3.0 \times 10^{6} \pm 0.1 \times 10^{6}$ & - & $3.0 \times 10^{6} \pm 0.1 \times 10^{6}$ & - \\
$3^{\text {rd }}$ days $2.75 \times 10^{6} \pm 0.3 \times 10^{6}$ & 6.25 & $1.02 \times 10^{6} \pm 0.1 \times 10^{6}$ & 66 & $4.29 \times 10^{5} \pm 0.8 \times 10^{5}$ & 85.21 & $2.50 \times 10^{4} \pm 0.3 \times 10^{4} 99.17$ \\
$6^{\text {th }}$ days $2.49 \times 10^{6} \pm 0.2 \times 10^{6}$ & 12.75 & $3.41 \times 10^{5} \pm 0.6 \times 10^{5}$ & 88.63 & $1.73 \times 10^{4} \pm 0.4 \times 10^{4}$ & 99.42 & ND & 100 \\
$9^{\text {th }}$ days $2.38 \times 10^{6} \pm 0.2 \times 10^{6}$ & 15.50 & $9.67 \times 10^{4} \pm 1.8 \times 10^{5}$ & 96.78 & ND & 100 & ND & 100 \\
\hline
\end{tabular}


Table 6: The effects and Reduction \% of chemical preservatives on S. aureus counts inoculated into minced meat samples $(n=5)$.

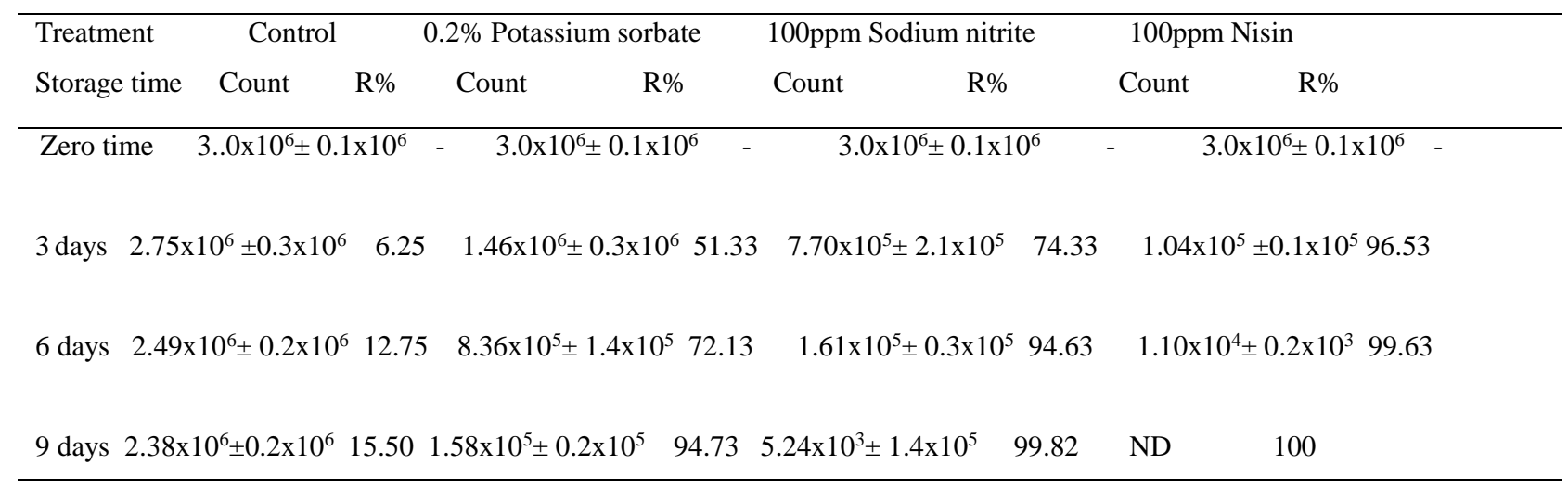

\section{DISCUSSION}

Minced meat is a highly perishable product due to its biological composition and the shelf life of refrigerated minced meat is limited by the growth and biochemical activities of aerobic bacteria. Minced beef can be easily contaminated with microorganisms and ,if not properly handled and preserved, support growth of pathogenic bacteria, leading to loss of quality and potential public health problems (Vernozy-Rozand et al. 2002).

\subsection{Antibacterial activity of cinnamon, garlic} and rosemary essential oils at concentration $1 \%$ against E.coli and S.aureus artificially inoculated in minced beef by intensity of $4 \times 10^{6} / g$ during cold storage at $\left(4 \pm 1^{\circ} \mathrm{C}\right)$

The presence of E.coli in food is considered as indicator of faults during preparation, handling or storage. It is also, considered as indicator of fecal contamination, beside. It may induce severe diarrhea in infants and young children, as well as food poisoning and gastroenteritis among the adults (Hassan, 2007).

Staphylococcus aureus is a leading cause of food poisoning resulting from the consumption of contaminated food with staphylococcal enterotoxins. Different foods act as a good medium for $S$. aureus such meat products (Guven et al. 2010). The Presence of S.aureus in meat products may be attributed to direct contact with workers with hand or arm lesions caused by S.aureus, or by coughing and sneezing, which is common during respiration infections. Food handlers are frequently the source of food contamination on staphylococcal outbreaks (Jennifer Hait, 2012).

Essential oils can act against resistance mechanisms in bacteria and tumor cells via plasmid curing and inhibition of efflux processes and may act indirectly by stimulating the defense mechanisms and the immune response (Trajano et al. 2010). Certain components of essential oils can act as uncouplers, which interfere with proton translocation over a membrane vesicle and subsequently interrupt ADP phosphorylation (Parasa et al. 2012). They can also interfere with membrane- integrated or associated enzyme-proteins, stopping their production or activity. Essential oils are also able to inhibit the synthesis of DNA, RNA, proteins and polysaccharides in bacterial cells (Chorianopoulos et al. 2007 and Akthar et al. 2014).

Table ( $3 \& 5$ ) indicated that the studied essential oils possess a significant antibacterial activity against $E$. coli and $S$. aureus, in the following order: Rosemary> garlic> cinnamon. These essential oils may be selected for use as potential antibacterial efficient and extend shelf life of minced meat. These findings were similar with those of Pranto et al., (2005), Barbosa et al. (2009), Babu et al. (2011) and Jolly and Menon (2015). 
The better effectiveness of essential oils against Gram- positive bacteria ( $S$. aureus) than Gram- negative bacteria (E. coli) may be due to volatile action of essential oils and due to absence of lipo-polysaccharide layer in Gram-positive bacteria that might function as an effective barrier against any incoming biomolecule (Delaquis et al, 2002).

In general, $\alpha$-Pinene is as major component of rosemary EO, followed by 1,8 cineole, $\beta$-myrcene, camphor and borneole. It was determined that Rosemary essential oil exhibits antimicrobial activity by passing through the cell wall and cytoplasm membranes and disrupting their structures as a typical lipophilic substance. Since damaged cell membrane increases its permeability, small molecular weight molecules such as phosphates and potassium ions first leach out from the cell, followed by larger molecules, such as DNA and RNA. 1.8-cineole exhibits a strong toxic effect on eukaryotic cells (Stojanovic-Radic et al. 2010).

These results may be attributed to the antibacterial effect of garlic apparently which results from interaction of sulfur compounds, like allicin, with sulfur (thiol)groups of microbial enzymes (such as trypsin and other proteases), leading to an inhibition of microbial growth (Jolly and Menon, 2015).

Cinnamon EO has gained greater acceptance among food technologists due to their better sensory evaluation and antimicrobial properties (Fischer and Phillips, 2006). The major component of cinnamon, cinnamaldehyde, possesses antimicrobial effects on microorganisms, as it inhibited cell wall biosynthesis, membrane function, and specific enzyme activities. More specific cellular targets of cinnamaldehyde are still required to be studied in detail (Sheraz et al. 2016).

4.2. Antibacterial activity of potassium sorbate (0.2\%), Sodium nitrite(100ppm) and Nisin (100ppm) chemical preservatives against $E$. coli and S. aureus artificially inoculated into minced beef by intensity of $4 \times 10^{6} / \mathrm{g}$ for $\mathrm{E}$. coli and $3 \times 10^{6}$ for $S$. aureus during cold storage at $\left(4 \pm 1^{\circ} \mathrm{C}\right)$

Food preservation is designed to enhance or protect food safety while maintaining or improving product quality by inactivating or inhibiting the growth of undesirable microorganisms (Ray, 1992).

Table (4\&6) revealed that nisin (100ppm) and sodium nitrite (100 ppm) had a higher antibacterial effect than that obtained by $(0.2 \%$ potassium sorbate) .

Also, S. aureus more sensitive to preservatives than E.coli, this results of the present study agreed with those obtained by Abdel-Shakour et al. ( 2014) who found that S.aureus as $\mathrm{G}+\mathrm{ve}$ bacteria showed high sensitivity to sodium nitrite higher than other $\mathrm{G}$-ve strains and found also when nisin was added as food preservative no growth observed for $\mathrm{Gm}+$ ve bacteria as $S$. aureus. This also agreed with Abou Hussein- Reham, (2012) who found that the growth of $S$. aureus in minced meat samples was completely inhibited after being treated with nisin.

Potassium sorbate inhibits certain amino acids uptake by E.coli interfering with its growth .However, the action of potassium sorbate is greatly dependant on $\mathrm{PH}$ of the food article where the low PH (1-4) had an apparent synergistic inhibition action caused by sorbate on the amino acid uptake by E.coli (Eklude, 2003).

The resistance of E. coli as Gram-negative bacteria against nisin depends on the type of lipopolysaccharide of the cell membrane. Consequently, addition of an agent to change the nature of the outer membrane of E.coli is very necessary to render the organism sensitive to nisin (Ganzle et al. 1999).

From these results illustrated in tables (4 \& 6), one can concluded that the use of chemical preservatives in certain concentrations have a benefit results in 
inhibiting such foodborne microorganisms that affect human health and causing public health hazards. It was concluded that the reduction percentage in $S$. aureus and E. coli counts artificially inoculated into minced beef samples increased by increasing the period of preservation.

Therefore, the effectiveness of preservatives depends not only on their concentration and type, but also on the species of microorganism on which they act (Stanojevic et al., 2009).

Finally, cinnamon, garlic, rosemary oils ( $1 \%)$, potassium sorbate $(0.2 \%)$, sodium nitrite (100ppm) and nisin (100ppm) can be used meat preservatives with antibacterial activities against food borne pathogens specially rosemary oil (1\%), garlic oil (1\%), nisin (100ppm) and sodium nitrite (100ppm) and therefore may be useful in maintaining the meat quality, extending shelf- life of meat products, preventing economic loss.

\section{Conclusion}

Rosemary oil (1\%) showed higher inhibitory effect on E.coli and S.aureus than that obtained by cinnamon and garlic oil (1\%). Nisin (100ppm) showed higher inhibitory effect on E.coli and S.aureus than that obtained by potassium sorbate $(0.2 \%)$ and sodium nitrite (100ppm). Staphylococcus aureus were more sensitive for essential oils and chemical preservatives than E.coli.

\section{REFERENCES}

Abdel-Shakour, E.H., Elouboudy, S.S., Abdelaziz, Z.K., Hassan, M.A. and Emara, M. B. (2014): Application of Bacteriocin as Bio-preservative in Foods" Adv. J. N Y Sci., 7(6):87-93.

Abo Hussien Reham, A. (2012): Detection of food mediated pathogens in some meat and chicken products by using recent techniques. ph. D. Thesis, Fac. of Vet. Med. Benha University.
Akthar, M.S, Degaga, B., Azam, T. (2014): Antimicrobial activity of essential oils extracted from medicinal plants against the pathogenic microorganisms: A review. Biological Sciences and Pharmaceutical Research, 2(1):1-7.

Babu, A., Sundari, A., Indumathi, J., Srujan, R.V.and Sravanthi, M. (20110): Study on the Antimicrobial activity and Minimum Inhibitory Concentration of Essential Oils of Spices. Veterinary World, 4 (7):311-316.

Barbosa, L.N., Rall, V.L., Fernades, A., Ushimaru, P., Da Silva, I. and Fernades, A. (2009): Essential oils against foodborne pathogens and spoilage bacteria in minced meat. Foodborne pathogens and Disease, 6:725-728.

Chorianopoulos, N.G., Evergetis, E.T., Aligiannis, N., Mitakou, S., Nychas, G. and Haroutounian, S.A. (2007): Correlation between chemical composition of Greek essential oils and their antibacterial activity against foodborne pathogens. Natural Product Communications, 2:419-426.

Delaquis, P.J., Stanich, K., Girard, B.and Mazza, G. (2002): Antimicrobial activity of individual and mixed fractions of dill, cilantro, coriander and eucalyptus essential oils. Int. J. Food Microbiol., 74:101-109.

Depoureq, G. and Poucke, L.V. (1991): "Evaluation of the microbial quality of minced meat “. P. 200 Food Policy Trends in Europe. Nutrition Technology, Analysis and Safety. 7476:75-79.

Eklude, T. (2003): The antimicrobial effect of dissociated and undissociated sorbic acid at different $\mathrm{PH}$ levels.J.Appl.Bacteriol; 72 (5): 249-255. 
Eleiwa- Nesreen, Z.H. (2003): "Effect of chemical preservatives on food poisoning bacteria in some locally manufactured meat products”. Ph.D. Thesis (Meat Hygiene), Fac. Vet. Med., Zagazig Univ. (Benha branch), Egypt.

Fik, M. and Fik, A. (2007): Microbiological and sensory changes in minced beef treated with potassium lactate and sodium diacetate during refrigerated storage .Inter.J.Food Properities, 10: 589-598.

Fisher, K. and Phillips, C.A.(2006):The effect of lemon,orange and bergamot essential oils and their components on the survival of Campylobacter jejuni, Escherichia coliO157;H7, Listeria Monocytogenes, Bacillus cereus and Staphyococcus aureus in vitro and in foodsystems.J.Appl.Microbiol.101(6):1 232-1240.

Food and Drug Adminstration "FDA (2002):" Food borne illness, what consumer need to know. Food Safety and Inspection Service.

Frankel, E., Huang, S.and Aeschbach, R. (1996): Prior E. Antioxidant activity of a rosemary extract and its constituents, carnosic acid, carnosol and rosmarinic acid, in bulk oil and oil-in-water emulsion. J. Agric Food Chem 44:131135.

Ganzle, M.G., Herd, C. and Hammes, W.P. (1999): "Resistance of Escherichia coli and Salmonella against nisin and curvacin A". Int.J.Food Microbiol., 48(1):37-50.

Guven,K., Mutla, B.M., Gulbandila, A.and Cakir, P.(2010):Occurrence and characterization of Staph.aureus isolated from meat and dairy products consumed in Turkey. J .Food Safety, 30:196-212.

Huq,M., Dutta,P.L., Suatan, N. and Rahman,A. (2013): Production and quality assessmentof fish burger from the grass crap, ctenopharyngodon idella (Cuvier and Valenciennes,1844),Journal of Fisheries, 1(1):42-47.

Harris, J.C., Cottrell, S.L., Plummer,S. L. and LIoyd, D.(2001): Antimicrobial properties of garlic. J. Appl. Microbiol and Biotechnol.57:282-286.

Hassan, Z.H. (2007): Studies on food poisoning microorganisms in some meat products. M. V. Sc. Thesis (Meat hygiene), Fac. Vet. Med. Menofia Univ., Sadat branch.

Hussein, A.M., El-Ghareeb, W.R., Lotfy,O.O. (2012): Shelf life improvement of camel meat treated with potassium sorbate $0.3 \%$. Journel of American Science, 8(4):507-511.

Jolly, D. and Menon,V. (2015): Antibacterial effect of garlic and ginger extracts on Escherichia coli and Listeria monocytogenes. International Journal of Applied and Pure Science and Agriculture (IJAPSA), 1(2): 111-118.

Lambert, A.D., Smith, J.P., Dodds, K.L. (1991): Shelf life extension and microbiological safety of fresh meat. Food Microbiol.9:267-297.

Leuschner, R. G. K. and Ieisch, V. (2003): Antimicrobial effects of garlic, clore and red hot chilli on Listeria monocytogenes on broth model systems and soft cheese. Int. J. of Food Sci. and Nut., 54:127-133.

Mangena, T. and, Muyima, N.Y. (1999): Comparative evaluation of the 
antimicrobial activities of essential oils of Artemisia afra, Pteronia incana and Rosmarinus. Officinalis on selected bacteria and yeast strains. Lett Appl. Microbiol. 28:291-296.

Mishra,N. and Behak, K.K.(2010): Antimicrobial activity of some spices against selected microbes. Int. J. Pharmacy and Pharmaceutical Sci., 2(3):187-196.

Olaoye, O.A. and Ntuen, I.G. (2011): Spoilage and preservation of meat a general appraisal and potential of lactic acid bacteria as biological preservatives. Review Paper. Int. Res. J. Biotechnol., 2:33-46.

Papagianni, M. and Anastasiadou, S. (2009): Pediocins: The bacteriocins of pediococci. Sources, production, properties and applications. Review. Microbial Cell Fractories, 8:1-16.

Parada, J.L., Caron, C.R., Medeiros, A.B.P and Soccol, C.R. (2007): Bacteriocins from lactic acid bacteria purification, properties and use as bio preservatives. Int. J. Brazilian Archives of Biology and Technol., 50:521-542.

Parasa, L.S., Tumati, S.R., Prasad, C. and Kumar, L.C.A. (2012) In vitro antibacterial activity of culinary spices aniseed, star anise and cinnamon against bacterial pathogens of fish. Int. J. Pharmacy and Pharmaceutical Sciences, 4(3):667-670

Pegg, R.B. (2004): “Curing”. In Encyclopedia of Meat Sciences. W. K. Jensen, C. Devine, and M. Dikeman, ed. Elsevier Ltd., Oxford, UK.

Pranoto,Y., Salokhe, V.M. and Rakshit, S.K.(2005): Physical and antibacterial properties of aliginate based edible film incorporated with garlic oil. Food Research International, 38(3):267-272.

Ray, B. (1992): "Nisin of Lactococcus lactis sub sp. Lactis as a food biopreservative".In: Food Biopreservatives of microbial origin. CRC Press, Boca Raton, Fla.PP:207-264.

Rosner, B. (2002): Fundamental of Biostatistics. $4^{\text {th }}$ Ed. (ed. P. W. Kent), Publishing Co. California, USA.

Shahidi, F. J., Arachchi, K.V. and Jeon, Y. (1991-1999): "Food applications of chitin and chitosans". Trends Food Sci. Technol., 10:37-51.

Stanojevic, D., Comic, L., Stefanovic, O. and Solujic-Sukdolak, S. I. (2009): "Antimicrobial effects of sodium benzoate, sodium nitrite and potassium sorbate and their synergestic action in vitro". Bulgarian Journal of Agricultural Science, 15(4):307-311.

Stojanovic-Radic, Z., Nesic, M., Comic, L. and Niko Radulovic, N. (2010): Antimicrobial activity and cytotoxicity of commercial rosemary essential oil (Rosmarinus officinalis L.) Biological Nyssana, 1(1-2):83-88.

Trajano, V., Lima, E., Travassos, A. and, Souza, E.(2010): Inhibitory effect of the essential oil from Cinnamomum zeylanicum Blume leaves on some food- related bacteria. Cienc. Tecnol. Aliment., 30 (3):771-775.

Vernozy-Rozand, C., Ray-Gueniot, S., Ragot, C., Bavai, C., Mazuy, C., Montet, M., Bouvet, J. and Richard,Y. (2002): "Prevalence of Escherichia coli O157;H7 in industrial minced beef".Lett.Appl.Microbiol.,35:7-11. 